\title{
Terveitä porkkanoita laatutuotteiden raaka-aineeksi
}

Terhi Suojala-Ahlfors ${ }^{1)}$, Tuija-Liina Laamanen ${ }^{1)}$, Päivi Parikka ${ }^{2)}$ ja Marja Lehto ${ }^{3)}$

${ }^{1)}$ MTT Kasvintuotannon tutkimus, Toivonlinnantie 518, 21500 Piikkiö

${ }^{2)}$ MTT Kasvintuotannon tutkimus, 31600 Jokioinen

${ }^{3)}$ MTT Kotieläintuotannon tutkimus, Vakolantie 55, 03400 Vihti

sähköpostiosoitteet: etunimi.sukunimi@mtt.fi

Tuorevihanneksia käytetään yhä enemmän prosessoituina tuotteina, kuten valmiina raasteina ja salaattisekoituksina. Tuotteiden säilyvyys ja mikrobiologinen turvallisuus ovat tällöin erityisen kriittisiä laatutekijöitä maun ja tuotteiden ulkonäön ohella. Hyvälaatuisten ja säilyvien jalosteiden edellytys on laadukas raaka-aine.

Osana TE-keskusten ja vihannesalan yritysten rahoittamaa Tuorevihannesten hygienia: raakaaineet, tuotteet, vesi ja jätteet (Tuovi) -hanketta selvitetään mahdollisuuksia parantaa erityisesti porkkanan laatua ja vähentää viljelyssä ja varastoinnissa syntyvää hävikkiä. Huomion kohteena ovat satoa varastoinnin aikana pilaavat sienitaudit, jotka ovat vakava ongelma myös käsittelemättömissä tuorekauppaan toimitettavissa porkkanoissa. Sienitautien hallinnassa keskitytään viljelymaahan: 1) kehitetään menetelmää, jolla voi testata pahimman varastotaudin, porkkananmustamädän, esiintymistä maassa ja 2) selvitetään maan ravinnepitoisuuden, mm. kalsiumin ja kaliumin, vaikutusta varastotautien esiintymiseen.

Tutkimus toteutetaan viljelijöiden pelloilla, jolloin tulokset ovat parhaiten sovellettavissa käytäntöön. Keväällä ja syksyllä 2009 kerättiin 18 porkkanalohkolta yhteensä 53 maanäytettä, joista selvitettiin maassa olevan porkkananmustamädän määrää käyttämällä porkkananpaloja pyydyskasveina. Syksyllä kerättiin porkkanasadosta näytteet, jotka varastoidaan MTT:n koevarastossa Piikkiössä. Varastoinnin aikana porkkanoissa esiintyvän taudin määrää verrataan maanäytteistä saatuihin tautiennusteisiin, ja arvioidaan näin maatestin luotettavuutta. Työ toistetaan kasvukaudella 2010.

Ravinnekokeita perustettiin keväällä 2009 viidelle porkkanalohkolle. Neljässä kokeessa on tutkittu lisätyn kalsiumlannoituksen vaikutusta porkkanan säilyvyyteen ja laatuun ja yhdessä kokeessa korotetun kaliumlannoituksen vaikutusta. Syys- ja lokakuun aikana koeruuduilta korjattu sato varastoidaan MTT:n varastossa Piikkiössä. Säilyvyystulosten ja porkkanoista tehtävien ravinnemittausten perusteella arvioidaan, mikä on suotuisin kalsium- ja kaliumtaso varastoporkkanan viljelyssä. Myös ravinnekokeita jatketaan kasvukaudella 2010.

Asiasanat: porkkana, Daucus carota, kalsium, kalium, porkkananmustamätä, Mycocentrospora acerina 


\section{Johdanto}

Porkkana on kaikkien tuntema monikäyttöinen juures. Se sopii niin laatikko- ja keittoruokiin kuin myös raakana syötäväksi raasteeksi ja dipattaviksi paloiksi. Porkkana onkin kulutusmäärillä mitattuna Suomessa kolmanneksi suosituin kasvis tomaatin ja kurkun jälkeen (Kotimaiset Kasvikset ry 2007). Yhä suurempi osa vihanneksista myydään prosessoituina tuotteina, joita ovat mm. valmiiksi pestyt porkkanat, raasteet, salaattisekoitukset ja välipalaksi sopivat naposteluporkkanat.

Kavisten prosessoiminen asettaa raaka-aineelle korkeat laatuvaatimukset. Prosessoidut kasvikset tarjoavat mikrobeille otollisen kasvualustan. Suomessakin on ollut useita ruokamyrkytysepidemioita joissa porkkanaraaste on ollut Yersinia pseudotuberculosis -bakteerin välittäjänä (Hatakka ym. 2004, Niskanen ym. 2005, 2007). Tuorekasvisten turvallisuus onkin noussut huomion kohteeksi.

Suomessa myydystä porkkanasta $92 \%$ on tuotettu Suomessa (Puutarhaliitto 2008). Porkkanan viljely on ammattimaista ja erikoistunutta tuotantoa. Kuitenkin sadosta menetetään vuosittain kymmeniä prosentteja pitkän varastointikauden aikana. Satoa pilaavat taudit, joista tärkeimmät ovat porkkananmustamätä (Mycocentrospora acerina), harmaahome (Botrytis cinerea), ja pahkahome (Sclerotinia sclerotiorum). Taudit aiheuttavat viljelijöille taloudellisia tappioita sadon menettämisen lisäksi pilaantuneen porkkanan hävittämisestä. Tautimäärä porkkanapelloilla vaihtelee voimakkaasti kasvupaikoittain ja vuosittain. MTT:ssä tehdyissä varastointikokeissa selvitettiin eri pelloilta kerättyjen porkkanaerien säilyvyyttä. Vuoden 2005 sadossa tautioireisten porkkanoiden osuus oli maaliskuussa 2-100\% ja vuoden 2006 sadossa 0-85\% (Vanhala 2008).

Taudit kulkeutuvat sadon mukana varastoon, jossa ne lisääntyvät. Tautien lisääntymistä voidaan hillitä sopivilla varasto-olosuhteilla, mutta ei täysin estää. Tautimäärä pellolla heijastuu säilyvyyteen varastossa. Erityisesti maalevintäisten tautien lisääntymistä pellolla on vaikea hallita. Viljelykierrolla voidaan vähentää tautipainetta, mutta taudit pystyvät lisääntymään ja leviämään myös rikkakasveissa. Tautiongelmaa voidaan pyrkiä vähentämään myös vahvistamalla kasvin taudinvastustuskykyä huolehtimalla hyvistä kasvuolosuhteista. Vanhalan (2008) tutkimuksessa ravinteiden, erityisesti kalsiumin, vaikutus varastotautien esiintymiseen osoittautui mielenkiintoiseksi.

MTT:n aiemmassa tutkimuksessa (Parikka 2008) kehiteltiin menetelmää maalevintäisen porkkananmustamädän määrän arvioimiseksi maanäytteestä. Menetelmän tulokset vaikuttavat lupaavilta, mutta testimenetelmä vaatii vielä lisätestausta ennen käyttöönottoa.

Tämän tutkimuksen tavoitteena on vähentää sadon pilaantumista, parantaa siten porkkanan tuotannon kannattavuutta sekä turvata hyvälaatuisen porkkanan saaminen elintarviketeollisuuden tarpeisiin ja kuluttajille. Sadon pilaantumista pyritään vähentämään kehittämällä testimenetelmää porkkanan pahimman taudin, porkkananmustamädän, tautiriskin ennustamiseksi. Tutkimuksen toisessa osassa pyritään määrittelemään pellon optimaaliset ravinnepitoisuudet hyvälaatuisen porkkanan tuotantoon.

Tutkimus toteutetaan osana Tuorevihannesten hygienia (Tuovi) -hanketta, jota rahoittavat TEkeskukset ja vihannesalan yritykset. Viljelytutkimuksen rahoitukseen osallistuu myös Maiju ja Yrjö Rikalan Puutarhasäätiö hankkeessa Porkkanan tuotanto 2010-luvulle: parempaa laatua, vähemmän jätettä. Hankkeet alkoivat vuonna 2009 ja jatkuvat vuoteen 2011.

\section{Aineisto ja menetelmät}

\section{Porkkananmustamätä -testi}

Porkkanapeltojen taudin määrää tutkitaan viljelijöiden porkkanalohkoilta kerätyillä maanäytteillä. Maanäytteitä kerättiin huhti-toukokuussa ja syys-lokakuussa 18 peltolohkolta. Jokainen peltolohko jaettiin kahdesta neljään osaan, joista kustakin kerättiin erikseen maanäytteet. Näytealueita oli siten yhteensä 53. Syksyllä kerättiin samoilta alueilta satonäytteet (n. $8 \mathrm{~kg} /$ näyte), joiden todellista säilyvyyttä MTT:n koevarastossa verrataan maatestistä saatavaan ennusteeseen.

Keväällä kerätyistä maanäytteistä testattiin porkkananmustamädän esiintymistä heti maanäytteiden keräämisen jälkeen. Lisäksi osa kevään maanäytteistä säilytettiin pakastamalla $\left(-20^{\circ} \mathrm{C}\right)$ syksyyn asti, jolloin testi tehtiin samanaikaisesti kevään ja syksyn maanäytteille. Testissä laitettiin puolen litran pakasterasian pohjalle $0,5-1,0 \mathrm{~cm}$ paksu kerros multaa, joka tiivistettiin painelemalla ja kostutettiin tarvittaessa. Mullan pinnalle asetettiin pestyistä ja kuorituista porkkanoista leikattuja, noin $0,5 \mathrm{~cm}$ paksuja porkkanakiekkoja. Testissä käytetyt porkkanat olivat samaa porkkanaerää, keväällä lajiket- 
ta 'Fontana' ja syksyllä lajiketta 'Nerac'. Suljetut testirasiat varastoitiin kuuden viikon ajan $15^{\circ} \mathrm{C}$ :een lämpötilassa, minkä jälkeen tarkistettiin porkkananpaloihin kasvaneen taudin määrä. Mycocentrospo$r a$-sienen runsautta arvioitiin laskemalla infektoituneiden porkkanakiekkojen määrä sekä määrittämällä mädäntyneen alueen osuus porkkanakiekosta. Tautimäärityksiä varmistettiin kasvattamalla taudinaiheuttaja mädäntyneistä porkkananpaloista agar-maljoilla (PDA). Varastointikokeessa mukana olevien porkkanoiden säilyvyys ja eri tautien pilaamien porkkanoiden osuus arvioidaan helmikuussa.

\section{Lannoituskokeet}

Kalsiumin ja kaliumin vaikutusta porkkanan varastokestävyyteen tutkitaan viljelijöiden pelloilla tehtävillä lannoituskokeilla. Kalsiumlannoituskokeessa (neljä koepaikkaa) tutkittavat lannoitustasot olivat kasvukaudella 2009: ei kalsiumlisäystä, kalsiumlisäys 575 kg/ha (Calsiniitti S 2500 kg/ha), ja kalsiumlisäys $1150 \mathrm{~kg} / \mathrm{ha}$ (Calsiniitti S $5000 \mathrm{~kg} / \mathrm{ha}$ ). Kalsiumlannoite levitettiin koeruutuihin keväällä ennen maan muokkausta ja kylvöä. Kaliumlannoituskokeessa (yksi koepaikka) verrattavat kaliumlannoitustasot olivat: $96 \mathrm{~kg} / \mathrm{ha}, 252 \mathrm{~kg} / \mathrm{ha}$ ja $400 \mathrm{~kg} / \mathrm{ha}$. Alin lannoitustaso sisälsi pelkän kevätlannoituksen, korkeammissa tasoissa kaliumia lisättiin kaliumsulfaattina kerran tai kahdesti kasvukaudella (23.6. ja 30.7.). Koeruudun koko oli $5 \mathrm{~m}$ x $10 \mathrm{~m}$, ja kukin käsittely toistettiin kolmena kerranteena, jotka sijoitettiin pellon eri osiin. Viljelijät tekivät kesän aikaiset hoitotoimenpiteet koeruuduilla samoin kuin ympäröivässä kasvustossa.

Koeruuduista kerättiin maanäytteet ennen lannoitteiden levittämistä sekä syksyllä sadonkorjuun yhteydessä. Jokaisesta koeruudusta kerättiin syyskuun lopulla porkkanasatoa kaksi noin kahdeksan kilon säkillistä varastointikokeisiin sekä 20 porkkanaa kuiva-aine- ja ravinnemäärityksiin. Porkkanat kerättiin käsin ja listittiin noston yhteydessä. Kesällä koepelloilta kerättiin säätietoja ilman lämpötilasta ja kosteudesta.

Kuiva-ainepitoisuus määritettiin porkkaraasteesta, joka kuivattiin $60^{\circ} \mathrm{C}: n$ lämpötilassa. Kuivatusta porkkaraasteesta määritettiin ravinnepitoisuudet MTT:n laboratoriossa. Kivennäisaineiden pitoisuudet määritettiin märkäpoltolla typpihapossa hajotetusta näytteestä ICP-OES:llä ja typpipitoisuus Kjeldahl-menetelmällä. Varastointikokeisiin kerätty sato varastoidaan kudotuissa PP-säkeissä MTT:n vihannesvarastossa Piikkiössä (lämpötila $0,5^{\circ} \mathrm{C}$, RH yli $97 \%$ ). Säilyvyys analysoidaan tammikuussa ja maalis-huhtikuussa, jolloin määritetään terveiden ja varastotautien pilaamien porkkanoiden osuus, sekä tunnistetaan taudinaiheuttajat.

\section{Tulokset ja tulosten tarkastelu}

\section{Porkkananmustamätä -testi}

Porkkananmustamätä -testin ensimmäisten tulosten perusteella porkkanapeltojen välillä on huomattavia eroja taudin määrässä (Kuvio 1). Toisaalta saman pellon sisällä taudin määrä voi vaihdella selvästi. Vain yhdellä pellolla tautia ei havaittu lainkaan. Syksyn näytteistä saatavien tulosten perusteella voidaan tarkastella sitä, missä määrin vaihtelu johtuu testistä itsestään. Kevättalvella saadaan tulokset sadon todellisesta säilyvyydestä varastossa, jolloin voidaan verrata testin antamaa ennustetta tautien todelliseen esiintymiseen porkkanoissa. Lisäksi peltolohkoista saatavien tietojen pohjalta voidaan arvioida mm. esikasvien merkitystä porkkananmustamädän esiintymisessä. 


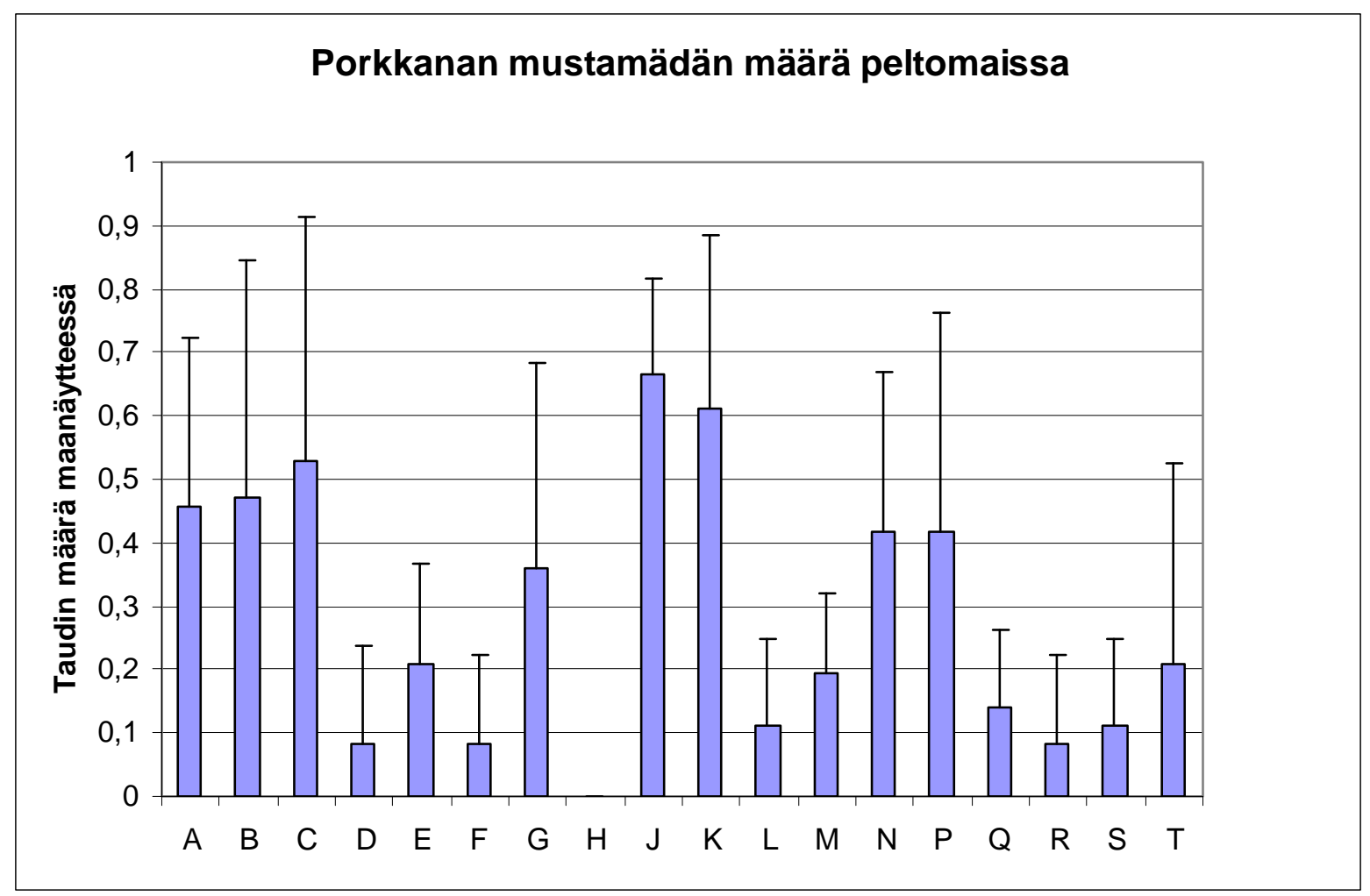

Kuvio 1. Porkkananmustamädän määrä testatuissa peltomaista keväällä 2009 otetuissa maanäytteissä. Taudin määrää kuvaava luku asettuu välille 0-1, jossa arvo 0 tarkoittaa, ettei tautia esiinny lainkaan, ja arvo 1 kuvaa taudin voimakkaasti saastuttamaa maata.

\section{Lannoituskokeet}

Lannoituskäsittelyt eivät vaikuttaneet porkkanasadon määrään, mikä oli odotettu tulos. Kalsiumlannoituksella ei saatu suurta vaikutusta maan kalsiumpitoisuuteen sadonkorjuun aikaan eikä porkkanan kalsiumpitoisuuteen. Kaliumkokeessa lannoitus nosti maan kaliumpitoisuutta syksyllä ja lievästi myös porkkanoiden kaliumpitoisuutta. Kalsiumlannoitus kipsivalmisteella lisäsi maan rikkipitoisuutta huomattavasti, mutta maan korkeampi rikkitaso ei nostanut porkkanoiden sisältämän rikin määrää. Kevättalvella 2010 saadaan tulokset sadon säilyvyydestä. Lannoituskokeet toistetaan kasvukaudella 2010.

\section{Kirjallisuus}

Hatakka, M., Johansson, T., Kuusi, M., Maijala, R., Pakkala, P. \& Siitonen, A. 2003. Ruokamyrkytykset Suomessa vuonna 2003. Elintarvikeviraston julkaisuja 7/2004. $42 \mathrm{~s}$. http://www.palvelu.fi/evi/files/55_519_315.pdf

Kotimaiset Kasvikset ry. Kasvistase 2006.

Niskanen, T., Johansson, T., Kuusi, M., Tuominen, P., Pakkala, P. \& Siitonen, A. 2005. Ruokamyrkytykset Suomessa vuonna 2004. Elintarvikeviraston julkaisuja 6/2005. $46 \mathrm{~s}$.

http://www.palvelu.fi/evi/files/55_519_351.pdf

Niskanen, T., Johansson, T., Siitonen, A. \& Kuusi, M. 2007. Ruokamyrkytykset Suomessa vuonna 2006. Elintarviketurvallisuusviraston julkaisuja 21/2007. 62 s. http://www.palvelu.fi/evi/files/55_519_511.pdf

Parikka, P. 2008. Porkkanan taudit. In: Vanhala, P. (toim.) Porkkanan kuluttajalaadun parantaminen. Maa- ja elintarviketalous 128: 105-121. Sähköinen julkaisu: http://www.mtt.fi/met/pdf/met128.pdf

Puutarhaliitto 2008. Puutarhanumerot. Puutarhaliiton julkaisuja nro 350. $27 \mathrm{~s}$.

Vanhala, P. (toim.). 2008. Porkkanan kuluttajalaadun parantaminen. Maa- ja elintarviketalous 128: 105-121. Sähköinen julkaisu: http://www.mtt.fi/met/pdf/met128.pdf 